\title{
Customer Integration and Beyond \\ Towards a Business Economic-Ethical Theory of the Firm
}

\author{
MiCHAELA HAASE ${ }^{* *}$
}

\section{Stakeholderintegration - Erweiterung der Kundenintegration und Ansatzpunkt zur Entwicklung einer ökonomisch-ethischen Theorie der Unternehmung}

The paper aims to make a contribution to the overcoming of what Freeman has characterized by his "separation thesis" and, based on a theory of the firm, the resources-processes-outcomes approach, developing of a business economic-ethics approach. The resources-processes-outcomes approach draws on two main theoretical concepts: integrative production and customer integration. The concept of customer integration throws light on the mutual responsibility of supplier and customer for the value-creation process and its outcomes. As regards management implications, customer integration can be interpreted as a special case of stakeholder integration. The paper outlines this program and proposes its implementation in two steps. Whereas the first step is mainly concerned with the statement, analysis and extension of the ethical dimensions of the available theory, step two shall contribute to the development of a business economic-ethical theory.

Keywords: Business Economic-Ethical Theory, Integrative Production, Customer Integration, Stakeholder Integration, Expectations, Stakeholder Management

\section{Introduction}

In business economics ${ }^{1}$ there are contributions which point out the economic-ethical dimensions of the assumptions of economic theories, or are of importance for the analysis or reflection of business-economic problems, or, from the perspective of business ethics, elaborate on the integration of business economics and ethics. ${ }^{2}$ That notwithstanding, business-economic theories usually abstain from a more intensive and systematic integration of their subject matter with that of business ethics. Still missing are business-economic theories which identify and solve economic-ethical problems, i. e., problems which evolve from a common perspective from the outset. Beyond

The article has been subject to a double blind peer review process. Date of submission: 6th September, 2007; revisited version accepted for publication: 14th June, 2008.

** PD Dr. Michaela Haase, Freie Universität Berlin, Otto-von-Simson-Str. 19, D-14195 Berlin, Germany, phone: +49-(0)30-83852135, fax: +49-(0)30-83854557, e-mail: michaela.haase@fuberlin.de, fields of expertise: theory of the firm, institutional economics, services economics, business ethics, philosophy of science.

1 As the paper mainly draws on an economic approach in the German Betriebswirtschaftslehre, it prefers the term "business economics" to "business administration".

$2 \quad$ Cp., e. g., Albach (2005, 2008); Küpper (2005, 2007); Ulrich (1987, 2001). 
economic ethics, ${ }^{3}$ in business economics theories which have accrued from common theory-building of business economics and ethics are far from being developed. Without such theory developments, however, the relationships between business ethics and business economics will probably remain rather sporadic.

This paper does not address the whole discipline of business economics. Its interest is limited to economic approaches subsumed to the theory of the firm. ${ }^{4}$ In this field, it sketches a theory of the firm - the resources-processes-outcomes (Haase et al. 2008) or "Leistungs" approach (Kleinaltenkamp/Jacob 2002) - based on the Gutenberg 5 school within German business economics. The resources-processes-outcomes (RPO) approach's analysis of interactions between firms and their customers also draws on the new institutional economics ${ }^{6}$ and the Austrian school of economics (Ehret 2007). From the perspective of the RPO approach, supplier-buyer or (to use a similar term) provider-customer interactions are analyzed in terms of "cooperative" or "integrative production"; this analysis throws light on the contribution of the customer to the value-creation process commonly undertaken with the provider. Both parties are responsible for the output or what they owe to each other and others.

Integrative production and customer integration that follows from integrative production as a topic of analysis as well as a management task, provide an interface to ethics, particularly to the stakeholder approach. The stakeholder approach is a businesseconomic contribution to management theory. ${ }^{7}$ The paper aims at the achievement of a unified view on firm performance, value creation, and stakeholder concerns, i. e., at a contribution to the overcoming of the schism between economics and ethics that takes place at the theoretical level in business economics as well as in business practice. This is not the only, but a systematic opportunity to overcome what Freeman (1994) has labeled the "separation thesis".

Currently, the relationships between business ethics and those strands of German business administration which are close to economics are characterized by the distance of "positive" (business) economic theories to the normative strands in business ethics. For this reason, the paper proposes to proceed in two steps: first, statement and analysis of the ethical dimensions of the available theory (Küpper 2007); second, development of a business economic-ethical theory that is built on broader foundations than the available theory (Steinmann 2008). However, divided in two steps, this paper only presents a first outline of what is here being called "extended RPO approach".

3 Cp., e. g., Koslowski (1986, 1992, 2008); Shionoya (2008); Ulrich (2001); Wieland (1996); Homann/Suchanek (2000).

4 The theory of the firm is no single theory but rather a family of theories.

5 According to Gutenberg, a firm is characterized by its system of production factors, cost effectiveness, financial equilibrium, the principle of economic acquirement (das erwerbswirtschaftliche Prinzip), self determination and autonomy (Albach 2008: 4).

$6 \quad$ Cp., e. g., Kleinaltenkamp/Marra (1995); Haase (2000); Haase/Kleinaltenkamp (2004); Kleinaltenkamp (2005).

$7 \quad$ Cp. Donaldson/Preston (1995), Stoney/Winstanley (2001), Freeman et al. (2004). 


\section{On the relation of economics and ethics}

Economics is the first social science that parted with philosophy. With it, a disconnection of aspects, which are connected within an economy or in social reality, has taken place at the analytical level. Nowadays, a separation of economic and ethical aspects at the theoretical level is prevailing; a division of labor between economics and ethics has therefore been established that, though not in general but with respect to economic ethics, shall be rolled back. However, there is no one best or unique way to characterize or determine the relationships between economics and ethics. The preferred types of relationships are depending on the ends which are to be achieved by a theory application, or by theory developments addressing inter- or transdisciplinary issues.

\subsection{Consequences of the academic division of labor}

As a consequence of the academic division of labor the question arises, how economics relate to ethics, and how the meanings of their terms are related. ${ }^{8}$ Ethics is a part of philosophy that is concerned with the justification, implementation, and enforcement of moral values, norms, and principles. Intermediated by human action, values, norms, or principles it can contribute to the realization of the ethical or moral good. As regards the justification of norms, the paper refers to two different views concerning the relationship between ethics and economics (Homann/ Suchanek 1987): According to the first view, ethical norms are analyzed and justified by ethics; as regards their enforcement, a contribution of economics is admitted. According to the second view, economics can contribute to the design and justification of ethical-economic norms.

The application of ethics to the domain of economics requires the empirical information of ethics about the domain of economics. In cases where ethics wants to inform itself empirically, to ethics is ascribed a primary, and to economics a subordinate position because ethics, its questions and problems provide the guide to the theory application. Genuine economic theory-building is usually not involved in this procedure; if at all, it emerges in the context of applications and deals with the divergences between to be and are to be, or how these might be reduced or eliminated, respectively. By this procedure the transfer of ethical principles or norms to the economics' domain is often combined with an approach to change matters within this domain.

In case of its subordination, economics does not contribute to the justification of values, norms or principles; to economics is assigned the status of an auxiliary science required for the implementation or enforcement of norms which have their origin in ethics. In order to put it in terms which probably more adequately characterize the application of an empirical theory: economics does not provide reasons for principles or norms which have their origin in ethics. From the point of view of ethics, in particular with respect to the application of ethics to the domains of empirical theories, this procedure is adequate. Such "impure" or "empirically informed ethics" (Nelson 2001: 225; Musschenga 1999) is usually not connected with the idea of changing economics or the assumptions of economic theories. Notwithstanding the investiga- 
tion and evaluation of economic decisions and actions from the exterior viewpoint of ethics has been misunderstood as providing substance to the impression that economic action is per se ethically deficient or in strict contrast to ethical action. ${ }^{9}$

If one addresses the relationships between economics and ethics, in particular with the aim of making a contribution to economic ethics, then the type and range of knowledge which can accrue from the above-sketched "application model" (Homann/ Suchanek 1987: 101) is too limited. The same would hold true for business ethics if only understood as "applied ethics". ${ }^{10}$ Business ethics goes beyond selective applications of ethics to the economic domain. It is characterized by several facets (Cowton 2008); one of them is a continuing, persistent process of theory-building addressing economic phenomena. Although economically informed ethics is not in general a misleading approach, it does not cover the requirement of theory-building at the intersection of economics and ethics; in addition, it will also not, at least not to a sufficient degree, contribute to the overcoming of the separation between (business) economics and (business) ethics.

With a focus on institutional development, the overcoming of the separation between economics and ethics is one goal of the program of the Homann School in economic ethics. They ascribe to economics a primary (or at least, a severe) role with respect to norm development and justification (Homann 1994, Homann/Suchanek 1987). This procedure is characterized by the application of economic theories to both the economic and the ethical dimensions of the problems in their domains. Models and policy proposals, which have implemented the ethical dimensions of the problems dealt with, can be an outcome of such a manner of advancement (Leschke/Pies 2005, Führ et al. 2007). An important attribute of this approach is that the impact of the ethical point of view is not restricted to ethical theories but already implemented in economic theories.

There are other approaches in economic ethics, as, e. g., Ulrich (1987), Ulrich (2001), Koslowski (2008), or Shionoya (2008), who work on the integration of the conceptual frameworks of economics and ethics, or elaborate on the meaning relations of their concepts. As regards the extension of the RPO approach, the works in these fields shall be of particular importance with respect to step two.

\subsection{The value judgment controversy and its consequences on the relations of business economics and business ethics}

This rigorous separation between to be (Sein) and are to be (Sollen) or between positive and normative economics (embodied particularly in the works of John Neville Keynes, Lionel Robbins und Milton Friedman) is a consequence of what is called the value judgment controversy (Werturteilsstreit) which took place at the beginning of the last century. Economics inherited a deep distrust or aversion against normative

9 For this reason, the actions of business people are often a priori ethically negatively evaluated but not those of teachers, physicians, or nurses (cp. Machan/Chesher 2002).

10 "In concept, business ethics is the applied ethics discipline that addresses the moral features of the commercial activity." (Marcoux 2008: 1; italics in the original) 
statements or value-laden judgments in theories. The positive-normative dichotomy has emanated from it, as well as the distinction between positive and normative economics that is subject to criticism for a long time (Blaug 1998, Myrdal 1976). The criticism focused particularly on the normative economics' neglect of the influence of values and evaluations on economic theory-building or theory-application, or on the idea that a clear separation of positive and normative theories or approaches is possible at all. The value judgment controversy and the developments subsequent to it have contributed to today's situation which can be characterized by an insufficient discussion of the role of values related to theory choice and theory development. Partially, this follows from a misunderstanding: Although valuations are not to avoid in general, they can become subject of reflection and criticism (Albert 1965 1980). The development of "positive" theories does not rule out the analysis of value-based actions. A reflection on values ${ }^{11}$ with respect to a theory, or its applications, does not imply the normativity of this theory; at least not in the manner that it makes valuations by itself or contains value judgments within its system of statements.

The relationship between business ethics and business economics has been affected by the value judgment controversy as well as by the answer to the question how the theories subsumed to the heading "business ethics" are to sort with respect to the normative-positive dichotomy. Normative business ethics' approaches often base on the adoption of norms from ethics and their application to economic problems. The acceptance of business ethics in the field of business economics is limited by its interpretation as a doctrine of pure principles (Steinmann 2008: 348). Business ethics has also been identified with a family of normative theories, which have won their most general principles from ethics. As regards the history of German business economics, Schönpflug (1954) characterized what is called the "ethical-normative approach" by Heinrich Niklisch (1876-1946) in the above-sketched manner. This approach was put into contrast to what is called the "theoretical-explicative approaches" in business economics (Weyermann/Schönitz 1912, Rieger 1928). In today's German business economics, the last-mentioned realm has become widely accepted (Chmielewicz 1979) - even though this is not tantamount to that today, the normative strand is without any influence (Schreyögg 1999). Not only have the aftereffects of the value judgment controversy gained influence on this issue but also the insufficient attention paid to the ethical dimensions of economic principles in general (Albach 2005, 2008).

\subsection{Theoretical placement of the resources-processes-outcomes approach}

The business economic-ethical theory of the firm outlined in this paper refers to the Homann School in business economics but also to other approaches in economic ethics. Insofar the paper aims at a clarification of the ethical implications of the RPO approach outlined in section 3, it is close to Albach's (2005) starting point. As it intends to contribute to the overcoming of the separation of the ethical and the economic point of view in theory and practice, it extends this starting point (Steinmann 2008). As a reaction to the skeptical stance of many business economists with

11 The values in question are not necessarily ethical ones. 
respect to normative theory-building, it will proceed in two steps. ${ }^{12}$ Table 1 provides an overview of the contents that shall be addressed by both steps:

\begin{tabular}{|l|l|}
\hline \multicolumn{1}{|c|}{ Step one } & \multicolumn{1}{c|}{ Step two } \\
\hline Ethically informed economics & Business economic-ethical theory (BEET) \\
\hline $\begin{array}{l}\text { Reversal of the separation of ethical and eco- } \\
\text { nomic dimensions of the value creation process } \\
\text { with respect to resources, processes, outcomes } \\
\text { - Accretion of ethicality to efficiency and } \\
\text { effectiveness ("triple E"); clarification of the } \\
\begin{array}{l}\text { interrelations and consequences of the Tri- } \\
\text { ple-E components }\end{array}\end{array}$ & $\begin{array}{l}\text { Investigation into problems identified by BEET } \\
\text { Meaning analyses and advancement of concepts } \\
\text { and conceptualizations in the light of BEET's } \\
\text { analysis }\end{array}$ \\
$\begin{array}{l}\text { Implementation or clarification of the } \\
\text { concepts of ethical and economic responsi- } \\
\text { bility; analysis of their impact on theory- } \\
\text { building and theory-application }\end{array}$ & \\
\hline $\begin{array}{l}\text { Extending "customer integration" to "stake- } \\
\text { holder integration" }\end{array}$ & $\begin{array}{l}\text { Advanced theoretical analysis on the introduction } \\
\text { of stakeholding in the conceptual framework of } \\
\text { BEET }\end{array}$ \\
\hline $\begin{array}{l}\text { Analysis of stakeholder management } \\
\text { Stakeholder governance } \\
\text { Norm development and justification within } \\
\text { the firm }\end{array}$ & $\begin{array}{l}\text { Theoretical analysis of norms or principles } \\
\text { involved in the formation of expectation } \\
\text { expectations }\end{array}$ \\
\hline $\begin{array}{l}\text { Analysis of the dialogic procedures undertaken } \\
\text { within firms and their consequences }\end{array}$ & $\begin{array}{l}\text { Theoretical analysis of the principles involved in } \\
\text { the justification of stakeholding or particular } \\
\text { stakeholder's interests }\end{array}$ \\
\hline
\end{tabular}

\section{Table 1: Two steps towards the development of a business economic-ethical theory}

Step one is conceived of being composed of several measures ${ }^{13}$ which altogether are directed at the overcoming of the separation of the economic and ethical dimensions of the value-creation process. At the beginning of step one, the ethically extended RPO approach is quite "ethically informed economics"; it begins with a systematic inspection of its main theoretical concepts and conceptualizations with respect to their ethical dimensions. In Table 1, three fields of analysis which have their source in the investigation into supplier-buyer interactions constitutive for economic value creation, are emphasized: Economic and moral responsibility; the "triple E" (efficiency, effectiveness, ethicality); customer and stakeholder integration.

12 This distinction is somewhat artificial and should neither be taken for an empirical description nor as a prescription of actual theory-development processes. In addition, that step two goes beyond step one does not imply that analyses subsumed to step one become redundant if a theorydevelopment process has achieved step two.

13 An exhaustive presentation of step one would presuppose the RPO approach's complete statement which cannot be rendered here. 
Economic responsibility is no term often used in economics though the subject is addressed in several fields related to law and economics, as, e. g., relational contracts or principal-agent relationships. Business economics usually assumes that the actors aim at the ends of efficiency or effectiveness (Hunt/Duhan 2002); these ends are amended by that of ethicality. In addition, to economic responsibility is added moral responsibility. A theoretical analysis of these concepts and the meaning relations between their economic and ethical characteristics will take place in step two. The knowledge achieved by the analysis of processes and activities from the economic as well as ethical point of view, will gain influence on the works in step two.

As regards step one, "sub-steps" towards the reversal of the separation of the ethical and economic aspects of the value-creation process follow the phase of ethical information and clarification. Based on the analysis of the theoretical as well as empirical consequences of measures directed at the overcoming of the separation of economics and ethics, the way is paved for a more systematic connection between the theoretical perspectives of business economics and (business) ethics, i. e., the development of a business economic-ethical theory that is able to identify and characterize common problems from the outset. ${ }^{14}$ Neither problems of business economics (as, e. g., the establishment of governance structures or leadership styles), which might be interpreted from an ethical perspective, nor ethical problems which can be identified in the domain of business economics (as, e. g., justice with respect to payment) are then addressed but, e. g., communications addressing issues in procurement, production, or sales from an integrated economic-ethical perspective.

The extension of customer integration to stakeholder integration refers to a main concept and subject of analysis of the RPO approach, i. e., integrative production and its consequences for the design of the firm's management. As regards management, the extension of customer integration to stakeholder integration constitutes the intersection of RPO and stakeholder approach (Freeman 1984). Insofar as it does not aim at the provision of own normative justifications of stakeholder interests (cp. Freeman 2004: 234), the RPO approach does not draw on the normative stakeholder approach. The extension of "customer integration" to "stakeholder integration" does not force the RPO approach to norm justification or development.

The management implications accruing from stakeholder integration are addressed and analyzed throughout step one. The RPO approach does not take over norms from ethics but allows for a transfer of procedural ethical approaches into management practice and its analysis. A dialogic justification of policies or norms within the firm is compatible with the procedure in step one. The contents of the dialogically justified policies or norms, however, are not prescribed by the RPO approach. The procedural approach is not part of the theory presented below; as regards the applications of the RPO approach, the procedural approach is within its tool box since it is helpful, or required, for tackling on a solution of the justification problems arising in firms. With respect to practice, the procedural approach has to be transformed into a management tool having, particularly, its expression in the firm's governance strucconcerning this matter can not be fully grasped yet. 
ture, culture, or communications. Step two extends the procedures described with respect to step one: Based on the analysis of the dialogical justification procedures and moral principles, which match with the stakeholder approach, it can address more advanced ethical-economic problems and become involved in economic-ethical theory-building. Section 3 introduces the PRO approach and elaborates in more details on the clarification and presentation of what is recorded in Table 1 concerning step one.

\section{The resources-processes-outcomes approach as the business-economic component of a business economic-ethical theory}

In business economics, there is more than one theory of the firm. By the expression "theory of the firm" is specified a family of approaches that emerged in consequence of the one-sided concentration of economics on markets. ${ }^{15}$ Erich Gutenberg developed the first theory of the firm within business economics that during the 1930's was still in its infancy. Gutenberg was impressed by the compelling nature of neoclassical theory; as regards the development of a business-economic theory of the firm, he aimed at a transfer of the economic style of analysis by means of models to business economics and their fruitful use there. His habilitation thesis (Gutenberg 1929) can thus be understood as the origin of the German business-economic theory of the firm. During the 1950's, Gutenberg became also the founder of a business-economic theory of the industrial firm that is shaped by theories of production and costs as well as by his works on sales and finance, which altogether are the origin of the functional view $^{16}$ of the firm in business economics (Wöhe 1986). The functional view of the firm has given rise to an analysis of segregated parts of the firm (like procurement, marketing, or sales) that tends to result in a neglect of the whole in favor of its parts.

The resources-processes-outcomes approach (RPO approach) has its origin in Gutenberg's theory of the firm inspired by neoclassics. The RPO approach is applied to problems related to business-to-business transactions (Engelhardt 1966, Kleinaltenkamp 1997) or business-to-business markets (Frauendorf et al. 2007); in the meantime, it has been evolved into a main approach in Germany's services economics (Corsten/ Gössinger 2005, Kleinaltenkamp/Jacob 2002). With it, from marketing theory, i. e., a functional approach, a theory of the firm has emerged that transcends the functional view on the firm in favor of a cross section analysis or view that relates to the entirety of the firm.

The change in the structure of the economy, apart from a goods-centered economy towards a services economy, has pushed the development of services economics of which the RPO approach is a part (Haase et al. 2008, Saab 2008). Services economics

15 During the 1940's, sociology specified the organization as object of analysis (i. e., not he firm, not the party, not the union a. s. o.). At about the same time, the organization (in the shape of the firm) became a subject matter in - what is now called - the new institutional economics (Coase 1937). Throughout previous decades, neoclassical economics has modelled the firm by means of a highly abstract production function.

16 This term should not be mistaken for what is called the "functional approach" within business ethics (for an introduction into the meaning of the term "functional view", cp. Brink 2008: 154f.). 
is insofar an adequate starting point for the paper's attempt to extend an available theory as it already emphasizes the role of the customer in the value creation process as well as its responsibility for both the process and its outcomes. Based on the production theoretical view harking back to Gutenberg, the customer's role is anchored in a characterization of the customer's input in the production process by productiontheoretical terms like "production factor" or "integrative production". The RPO approach has extended this view with respect to the disposition of factor combinations (Kleinaltenkamp/Haase 1999) undertaken by supplier and customer as well. Under the heading "customer integration" (cp. Kleinaltenkamp et al. 1996) the common value-creation process by supplier and buyer is analyzed, and the consequences on the design of the firm's management are outlined. Customer integration, its analytic as well as its management dimension, ${ }^{17}$ exerts influence on the whole firm as, e. g., its business strategy, governance structure, and working operations. For this reason, the $\mathrm{RPO}$ approach has evolved from a marketing approach into a theory of the firm, even though it is a far cry from being completed, or having even fully devised all parts of its theoretical framework.

From the RPO approach's perspective, the overarching term to any kind of activities executed within the organization ${ }^{18}$ is "production". This is a consequence of its heritage from Gutenberg; nevertheless, the RPO approach's concept of production is much broader than that of Gutenberg because it does not only take into account mechanical or machine-based production but any kind of combinations of factors of production. ${ }^{19}$ The RPO approach has extended Gutenberg's theory of the firm with respect to the understanding of factor combinations which, from the RPO approach's point of view, are subject of the disposition of both supplier and buyer; in addition, a distinction is made between preparative and integrative production. Based on knowledge from law and economics, the RPO approach also investigates into the impact of property rights in production factors.

\subsection{Preparative and integrative production}

The RPO approach makes a distinction between preparative production and integrative production: "Preparative production" subsumes all activities which have to be finalized prior to the begin of a joint production process with a single customer, i. e., the procurement and pre-combinations of production factors which are in the ownership of and governed by the supplier. The production-theoretical view is attended by a relationship perspective that, in case of preparative production, singles out relation-

17 Whereas each value-creation or production process is undertaken by a single firm and a single customer, the management tasks following from it go beyond it; they are, e. g., directed at the adaption of the available governance structure to the implementation of new governance structures for single customers.

18 Investments into the firm's resource pool, which may be temporarily limited or unlimited, characterize its borderline.

19 This includes for example the production of knowledge as a public good by a scholar who does so as an agent of his or her university or the production of knowledge as a private good by a scholar who works for a private company. 
ships between the firm and its subcontractors, or network relations within supply chains, or value chain communities (Haase/Kleinaltenkamp 2004).

Compared to "preparative production", "integrative production" is a different theoretical construct expressing the view that supplier and buyer ${ }^{20}$ jointly produce the firm's output. This requires that the customer brings along own factors of production, and invests them temporarily (for the time a transaction takes) into the coproduction with the supplier. The supplier's factors of production - the internal factors - and the buyer's factors of production - the external factors - are both necessary in order to produce the firm's output. As displayed in Figure 1, external factors are persons, in many cases the customer himself or herself, objects, property rights, nominal goods, and information. Internal and external factors are to combine throughout the process of integrative production. The customer is not only conceived of a supplier of production factors brought in into a production process undertaken and completely governed by the supplier of the output, or a temporarily limited investor into the firm's resource pool, respectively. Although to a different degree, depending on the idiosyncrasies of the outcome and the interests of the customer, supplier and customer are being forced to cooperate throughout the production process jointly undertaken and governed by either of them.

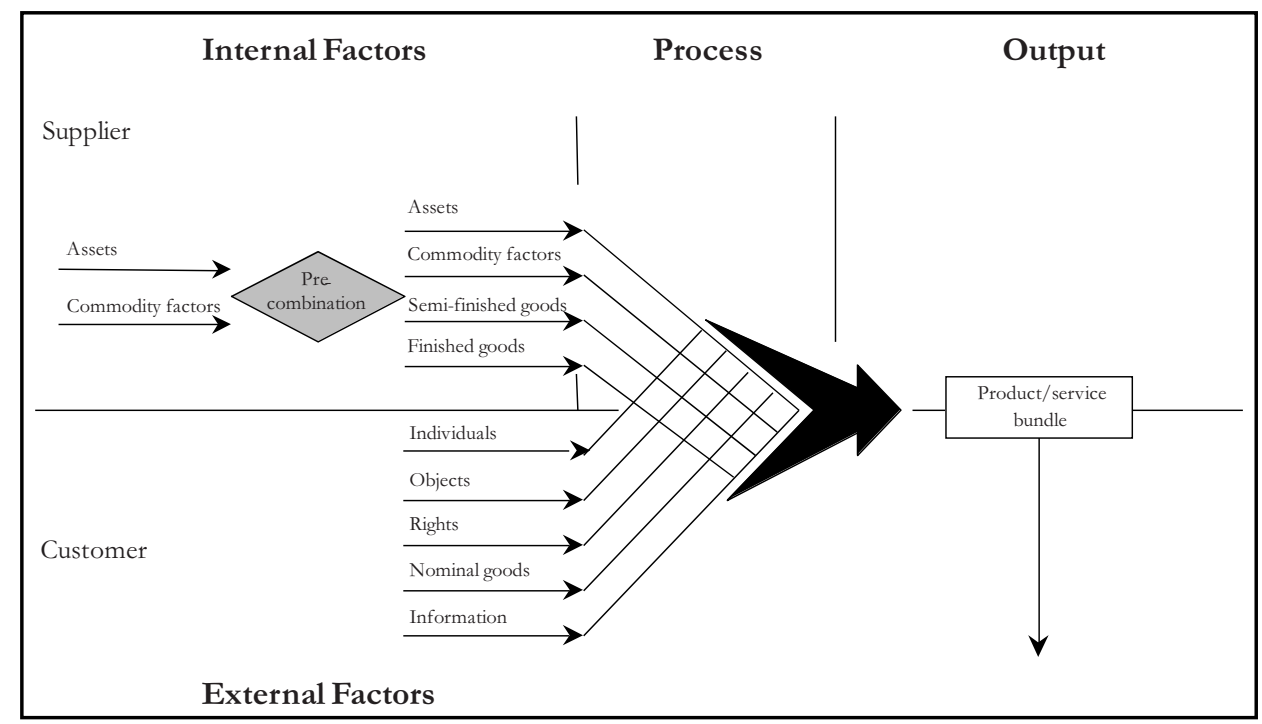

Figure 1: The integrative value-creation chain (Fließ/Kleinaltenkamp 2004: 394)

In the RPO approach, the coproduction between provider and customer is captured by the term "integrative production" whereas its consequences on analysis, design and

20 The RPO approach generally refers to the supplier (or provider) and the buyer (or customer) of the output, even though behind these labels mostly hide firms (in case of business-to-business transactions) or firms and households (in case of business-to-consumer transactions), or the individuals who act for these organizations. 
governance of the production process, as well as its output, are covered by the term "customer integration". Usually, efficiency and effectiveness are the ends of economic activities supposed by business economics (Fließ/Kleinaltenkamp 2004). The first is tantamount to the familiar economic principle; the second addresses a provider's ability to identify and to solve the customer's problems. "Efficiency" addresses how the relations of ends and means are to evaluate economically; "effectiveness" addresses how a particular means-ends relation contributes to the solution of a customer's problems. The "voice of the customer" makes itself heard by means of effectiveness that is also an end to take into account regarding the task of customer integration. Effectiveness requires a systematic interlocking of a firm's communications mainly having their origin in interactions within the firm or between supplier and customer. It is one task of the marketing division to communicate the firm's output into the market as well as to establish the preconditions for an intake of the "market's answer" to the firm's offers, including its response to the semantics of the firm's outcomes (Priddat 1998) or the firm's identity (Schramm 2008). Till now, the RPO approach addresses the impact of the market demand on a firm particularly with respect to the end of effectiveness: it selects from the set of action opportunities those, which are the best suited for the solution of the customer's problems. The communication processes related to customer integration are decisive for the identification of a customer's interests and ends. As regards the output, ethical aspects can be taken into consideration as any other requirements.

From the perspective of the RPO approach, marketing management is responsible for the design of the relevant units of economic organization. It outlines and organizes the preconditions required for the combination of production factors, property rights, and information. The tasks of marketing management thus affect the whole firm. The organization has to become adapted in such a manner that it can fulfill the above listed requirements related to customer integration. The RPO approach emphasizes the linkage between what Commons (1931) has called "bargaining transaction", on the one hand, and "managerial transaction", on the other. Bargaining transactions are market transactions executed within or by means of arrangements related to the market. Managerial transactions are intraorganizational transactions executed by means of arrangements set up by the organizations involved in the transaction. The tasks arising from agreements between supplier and customer are negotiated within the institutional, organizational, and technical framework related to the bargaining transaction. After their negotiation and determination, these tasks "pass" the firms" borderline. They are introduced into the supplying and buying organization and finalized inside of them by means of managerial transactions.

A far-reaching challenge for economic organization is the provision of a structure for factor combinations which can tackle with the influence the customer can gain on the governance of the whole production process: "Customer integration" draws on the analysis of two - related - dimensions specifying the customer's activities within the firm: first, the provision of input factors into factor combinations and disposition of factor combinations; second, the customer's influence on the governance of the processes related to factor combinations. "Disposition" means that the customer does not only contribute to the factor combinations in the sense that he or she provides 
resources necessary for the production process; rather, it reflects that in many cases the customer also gains influence on the governance of these combinations. ${ }^{21}$ The customer's gain in influence and control restricts the supplier's decision and action autonomy. 22

As regards customer integration, there is no fundamental difference between businessto-consumer (BtC) and business-to-business ( $\mathrm{BtB})$ transactions. Compared to $\mathrm{BtC}$ transactions, a more intensive cooperation characterizes BtB transactions; in addition, $\mathrm{BtB}$ transactions are more often subject to long-termed dispositions and characterized by more enduring interactions than $\mathrm{BtC}$ transactions. $\mathrm{BtB}$ transactions usually demand for a higher degree of involvement into the joint production process than $\mathrm{BtC}$ transactions. By intention or by chance, a series of $\mathrm{BtB}$ transactions can evolve into what is called a business-to-business relationship. ${ }^{23}$ The more intensive or enduring the coproduction of both parties, the better the customer's opportunities to assess the supplier's performance, his or her ability and will to create value for the customer, on the one hand, and his or her ability and will to do this in an ethically or morally reflected manner, on the other.

The RPO approach's focus of analysis is based on the entire organization. The approach has developed a general model of firm activities that reflects the division of labor within the firm. Only indirectly grasped by this model are distinctions, which have their source in Gutenberg's theory of the firm (Gutenberg 1929) and have led to the development of different functional areas within firms, e. g, procurement, marketing, or finance. In addition, all relationships which arose due to managerial transactions are indirectly dealt with, namely the principal-agent relationships between a firm's leaders, its middle management, and its employees. The distinction between stakeholders, which make permanently available resources to a firm (in particular, stockholder, employees, and management), and others, which provide resources only for the time a transaction takes (in particular, the customers) has been elaborated on only insofar as it was required with respect to the subject of interest. "Customer integration" subsumes the management implications accruing from the analysis of the common production process. "Integration" is thus a term which can be understood in a broader sense than "integrative production": "Integration" requires that the firm reacts (or responds) to the expectations of its respective customers and adapts its organizational or governance structure accordingly. Customer integration is a management task addressing the combinations of internal and external factors of production, i. e., integrative production. Specific organizational, technical, and institutional arrangements provide the framework that governs these activities. The framework has

$21 \quad$ Note that usually customers are not interested in gaining a degree of influence on the governance of factor combinations going beyond that one which is - from an economic or ethical - point of view required.

In Gutenberg's theory of the firm, such "governance rights" are only assigned to the supplier (Kleinaltenkamp/Haase 1999).

23 The Anglo-Saxon literature in services marketing often puts into opposition the terms "transaction" and "relationship" (cp., e. g., Vargo/Lusch 2004). The paper does not follow this line of argumentation as, according to Commons (1931), the transaction is a unit of analysis mainly characterized by relationships of the parties to a transaction. 
to be designed according to the above-mentioned ends of economic activities: efficiency, effectiveness, and according to step one - as amendment - ethicality. The next subsection will further elaborate on the interface between economics and ethics accruing from customer integration.

\subsection{Customer integration and the symmetries of responsibility}

In business economics, it is common to analyze the problems within its domain from the perspective of the supplier, or the offering firm. ${ }^{24}$ Customer integration is thus interpreted as a problem that has to be addressed by the supplier. This follows from the assumption that the supplier prepares the drafts or blue prints (Fließ/Kleinaltenkamp 2004) for the economic organization of the supplier-buyer interactions or processes necessary for the attainment of the output, i. e., the supplier is assumed to be the party that holds superior knowledge about amount and details of the collaboration between himself or herself and the customer. ${ }^{25}$

Cooperation with the customer is required because he or she holds the property rights to the external factors without which the production of the output is impossible. The customer's property rights to his or her assets are the ultimate reason for a limitation of the supplier's range of disposition or of his or her autonomy ${ }^{26}$ with respect to the decisions and actions related to the common production process. They are also the reason for the economic responsibility of the customer for the outcome as well as the manner it is brought about. Besides the common interests of supplier and buyer in the accomplishment of their ends, there are also diverging interests, which, insofar they are made explicit throughout the course of a transaction, can become the subject matter of the bargaining processes.

The interactive or cooperative production between provider and customer takes place to a different degree: In cases characterized by output scarcely composed by preproduced components, or if the adaptation of output and process to the requirements of the customer is rather high, the reasons for cooperation are many. Cooperative production takes place in $\mathrm{BtB}$ transactions (i. e., within the supply chain) as well as in $\mathrm{BtC}$ transactions. A supplier can only meet a customer's demand for moral production if he or she accepts his or her responsibility within the supply chain, too. Although it is true that "the market relieves the entrepreneur from his or her ethical obligation to

24 Note that the expressions "supplier" and "buyer" designate firms or organizations, no individuals.

25 Both supplier-customer- and customer-supplier-relationship are principal-agent relationships characterized by asymmetric information. For discussion of this relationship in business ethics, see Bowie/Werhane (2005: 62ff.).

26 The autonomy based on a firm's freedom to make contracts is not restricted. The autonomy based on the capital owners' residual decision rights, whereas the interests of all other stakeholders are considered by contracts (Albach 2008: 5), is restricted from the perspective of the RPO approach. 
include the utility function of the other into his own one“ (Albach 2008: 15), ${ }^{27}$ this relief is limited by the character of negotiations which have as their subject the other party's utility or action opportunities resulting from the market transaction. Often, in particular if a transaction is designed under the influence of one party's superior market power, the other party does not dispose of a great range of influence regarding the contents of a transaction. Despite the above-mentioned relief of the market, time or costs prevent that everything, even everything of interest, can become subject of negotiation. From this, it follows that customers become involved in market transactions though they do not agree on all of their details. In many transactions, the customer can doubt that what is called in the information economics the search, experience, or confidence qualities of an output are available, in part or complete. ${ }^{28}$ In addition, insofar it has not been the subject matter of communications between supplier and buyer, it is left open if in the course of a bargaining transaction the interests of other stakeholders have, or have not, also been taken into account. The customer is not expected to be able to negotiate on these issues in full amount.

As the considerations above should have made clear, the customer is not indifferent with respect to the issue if the supplier does or does not connect economic and ethical reflections on his or her own motivation. A supplier, who only reacts to the market demand with respect to the ethical dimensions of value creation processes, as well as their preparation and output, will probably not implement more ethical attributes (or parameter values, which express their availability to a greater degree) than the customer is able to inspect or experience. This attitude, of course, is not tantamount to an opportunistically motivated reduction of the output's value; rather, it is in accord with the supplier's fulfillment of obligations from the point of view of voluntarism (Cappelen 2004: 320f.). ${ }^{29}$ If legal regulation falls behind the parameter values aimed at by a customer, it can happen that he or she will not be able to achieve his or her aspired level of satisfaction. Concerning the confidence attributes of the output, which cannot be observed or experienced by the customer, there is a real danger that he or she will not obtain what he or she intends to pay for or believes to support. In such cases, the supplier will extend his or her economical considerations only if the customer demands for the realization of the required expressions of confidence attributes because only then the expectation is justified that the higher costs of the morally superior offer can be realized in the market. The customer will probably not be willing to pay for something that he or she has not demanded. The market is thus not amoral; it is as

27 In original terms: Es ist zwar richtig, dass „der Markt den Unternehmer von seiner ethischen Verpflichtung (entlastet), in seine Nutzenfunktion das Wohl des Nächsten einzubeziehen“" (Albach 2008: 11).

28 According to information economics, attributes of goods are identified by means of informationsearch processes, or experience. If the search for information is too expensive, then, based on cost-benefit considerations, the individual has to decide whether or not to stop further search and instead of it to rely in the supplier. Cp. Nelson (1970), Darby/Karni (1973).

29 "In the absence of any voluntary agreements, the only obligation we have towards other individuals is the negative duty not to violate their basis rights. Positive obligations between individuals might be legitimate only if they are voluntary agreed and the agreement did not violate any individual rights.” (Cappelen 2004: 321) 
moral as the market participants are, as well as the legal rules, which inform and guide their actions.

The market demand plays an important part in the realization of amount and quality of moral production. On the one hand, it is a restriction for these suppliers who intend to produce morally on the basis of their own motivation as well as for those who do not intend that. On the other, it is a drive mechanism for the consideration of interests of stakeholders - though not of all interests of all stakeholders but only of those, for which stakeholders themselves stand up for in the course of their transactions. As regards both bargaining transaction and integrative production, both parties $^{30}$ involved in them and their governments are responsible for the activities and processes, and their outcomes, which take place there. The concept of responsibility can thus conceived of, as one of mutual responsibility, i. e., a four-digit relation that is symmetric with respect to the variables designating supplier and buyer: ${ }^{31}$ The supplier is responsible to the customer (and vice versa) for the process of value creation (and its outcomes) according to specific standards. ${ }^{32}$

That the relation between supplier and customer is symmetric, does not exclude that they can be responsible to a different degree (Lenk/Maring 1992: 162). ${ }^{33}$ In addition, within firms or households, or other kinds of organizations, economic as well as ethical responsibility is distributed among individuals, though not equally distributed. The range of action opportunities restricts the degree of responsibility ascribable to each individual (or firm). Managers ("superiors" in a managerial transaction according to Commons' terminology) are probably responsible for a greater number of actions than other employees ("inferiors" in a managerial transaction according to Commons), or for other kinds of actions, respectively. An organization can thus be understood as a system of responsibility (Verantwortungssystem, Werner 2006: 545).

Mutual responsibility characterizes all activities which are undertaken in order to prepare the joint coproduction with the customer. It is also ascribed to both supplier and customer if the joint process of value creation goes after unethical interests or aims at unethical ends, or is characterized by use of questionable means (children's work, human rights violation, discrimination, violations of the principle of sustainabil-

30 According to French (1979), corporations can be conceived of full-fledged moral persons. Werhane (1985) introduced "second order actors" or "second order responsibilities" in order to avoid a commitment to the metaphysical existence of corporations.

31 The core meaning of the term is "to be responsible for X with respect to $\mathrm{Y}$ considering $\mathrm{Z}$ " (Werner 2006: 542, translated by M. H.); original terms are: „In der Kernbedeutung des Begriffs heißt, sich für X gegenüber Y unter Berufung auf Z verantworten' soviel wie ,sich (für X gegenüber Y unter Berufung auf Z) rechtfertigen“.

32 "Standard" refers to the objective dimension of responsibility which has been analyzed in terms of causal relations between (positive as well as negative) causes and effects (Ladd 1992).

33 That responsibility is related to action opportunity (as well as other aspects not discussed here like the reasonableness of actors) applies to the relationships inside of firms (or corporations) as well as to the relationship between supplier and buyer. Based on this understanding, it is the supplying firm $F$ but no individual who acts for $F$ which owes the outcome endowed with the attributes negotiated on throughout a bargaining transaction to the buyer. 
ity, a. s. o.). If there are opportunities ${ }^{34}$ available to catch up on the ethical aspects of one's actions, if there are ranges of action which allow for ethical actions, ethical responsibility is assumed..$^{35}$ If the customer is not only interested in a solution of his or her problems but also in the manner how it is brought about, then ethicality is linked with effectiveness. ${ }^{36}$ Otherwise, even if suppliers or customers are not concerned with the ethical dimensions of their common endeavor, based on their autonomy and reasonableness, on the one hand, and their capacity to respond to the messages from their stakeholders, on the other, they are nevertheless economically and ethically responsible. In all cases where an actor disposes of decision autonomy, i. e., if there are opportunities as well as ranges for self-governed action, then the actor is responsible for his or her decisions and actions in both economic and ethical respect.

Against the background of this understanding of the concept of responsibility, when individuals or firms intend to become involved into a transaction with another market participant, they have to reflect on both the economic and the ethical dimensions of the joint endeavor. The realization of the joint value-creation process requires therefore that the involved actors dispose of competences with respect to economics and ethics. For these reasons, the RPO approach amends the two economic ends - efficiency and effectiveness - by ethicality.

\subsection{Stakeholder integration and communication}

According to the RPO approach, the concept of customer integration refers to two stakeholder groups: first, to the final consumer (who, from the marketing point of view, is the ultimate reason for all activities within supply chains) and, second, to the firm that acts within supply chains. Each firm acts thus in several roles: it directly interacts with those who request its output; or it is involved in interactions with its own subcontractors or other firms in networks of firms. Customer integration (which can be seen as a task, or a process, or a consequence of a process) is the consequence of the joint production of output between a firm and a customer (as a member of a particular group of stakeholders, namely the customers). For this reason, the customers hold a particular position among the stakeholder groups. ${ }^{37}$ Beyond customers, the analysis of the value-creation process (and its preparation) has provided reasons for a reflection on the role of other important stakeholder groups: employees, management, consumers which are not customers of the firm, other firms within the supply chain. Whereas "integrative production" is restricted to supplier-customer interactions,

$34 \quad$ Albachs (2008: 10) remark that “it is questionable if the transaction partner's wealth (utility) can be always and in all circumstances correctly identified“" (translation by M. H.) is to take seriously. The actor is nevertheless obliged to exert himself or herself for it.

35 The paper does not discuss presuppositions of moral responsibility addressed in ethics as, e. g., being a moral person (French 1979), or an autonomous being capable of self-governance (Bowie/Werhane 2005: 43).

Actually, this is the second time that effectiveness and ethicality join. The first time this takes place is in the specification of the customer problem throughout the bargaining transaction which is to be solved by means of the coproduction of supplier and buyer.

Cp. Bowie/Werhane (2005: 61ff.). 
"integration" as a management task can also apply to relationships with other stakeholders than customers. Against the background of the stakeholder approach, which can be interpreted as a business-economic contribution to management, ${ }^{38}$ the paper proposes an extension of "customer integration" to "stakeholder integration".

Insofar communication has been a subject matter in the RPO approach (Haase 2003), it focused on the attributes of output, or the government of processes related to customer integration. Ethical dimensions of output or ends related to the joint production process (or its preparation) are not taken into account, at least not explicitly or under the heading of ethics. A theory of the firm that is anchored both in economics and ethics does not separate the firm's performance and output from its ethical stance. The determination of the ethical content of a firm's communications requires that the firm reflects on itself, its ends and values as well as its relationships to its stakeholders. In order to grasp these developments theoretically, the RPO approach can be extended in a double way: first, it takes into account all stakeholders (customers, subcontractors, employees, policy, or "local communitie", cp. Cappelen 2004: 319) with which the firm communicates due to its performance and the output jointly created with single customers. Second, it analyzes, the firm's consideration of the ethical dimensions of its activities and the consequences therefrom.

From a firm's point of view, stakeholder integration requires the implementation of organizational and institutional interfaces for the execution of transactions with stakeholders, which extend sporadic communications. In analogy to the tasks, which the firm faces with respect to customer integration, it has to generate the organizational, institutional, and technical preconditions for the stakeholder's participation in processes which sometimes are limited to communication but may also get extended and give reason for other kinds of actions as are, e. g., change processes. However, a firm's governance structure is oriented at the maintenance of durable relationships with only some stakeholders, namely those called key stakeholder (Freeman 2004: 229). If a firm has thus integrated stakeholders, with it, it has accepted or legitimized their interests or concerns. This legitimation is, of course, limited.

The development of relationships between a firm and its stakeholders begins with the upcoming of expectations on the expectations of the stakeholder, which are related to the firm's activities and performance. As regards the firm, thus, expectations on expectations identify particularly external stakeholders. Expectations of customers, which refer to the concrete output they have produced together with the firm, are subsumed under the concept of stakeholder expectations. The performance of the firm, or the value-creating processes together with the customer, is then the firm's response to the expectations of a particular stakeholder group, namely the customers. ${ }^{39}$ If this principle is transferred to the other stakeholder groups, then "customer integration" turns out to be a special case of a more general concept of stakeholder integration.

\footnotetext{
38 For references, see note 7.
}

39 Actually, it is a response to single members of this group, namely those who interact or have interacted with the firm. 
That stakeholders are identified by expectation expectations holds also true in cases in which stakeholders have not already tried to make their voice heard to the firm. Stakeholders who believe that their concerns are not adequately addressed by a firm can try to get support regarding their issues by getting into contact with third parties as, e. g., NGOs. That a firm has noticed the expectations of stakeholders will probably not satisfy the most of them; they will presumably demand for a more far-reaching reaction of the firm. In any case, the response of a firm expresses its answer to what it conceives of the stakeholder's expectations.

As there are assumed interest conflicts between stakeholder groups ${ }^{40}$, the implementation of stakeholder integration can give rise to additional conflicts. It is thus of advantage to make the system of responsibility as explicit and broad as necessary. Those who have permanently invested into the firm's resource pool and are involved into the value-creation process ${ }^{41}$ should agree on the content, too. It should not only be approved by a small group within the firm, e. g., the management; instead of this, the firm's response should express a consensus of the different internal stakeholder groups. Otherwise, it is not expected that a response affected both by economics and ethics can be maintained for longer than a limited period of time. Included in this consensus is an agreement on the matter to which of the stakeholders' expectations an answer is provided, or how the firm deals with interest conflicts. Procedural ethics as for example dialogue ethics (Steinmann/Löhr 1994) may provide an adequate means for the accomplishment of these tasks.

The formation of expectation expectations precedes their legitimation that is in need of justification in any case. ${ }^{42}$ The legitimization of stakeholder interests or concerns is no absolute measure but an attribution that harks back to the internal stakeholders of a firm. Both, the formation of expectation expectations and the response to them are consequences of processes which take time and can be analyzed by means of historic and pragmatic conceptions. As Werner (2006: 547, translation by M. H.) argues with respect to the concept of responsibility, ,in discourse ethics, the unlimited community of all rational beings is accepted as the proper instance of moral responsibility; with it, the fallibility of all trials directed at empirical justification is addressed“".43 The same applies to the legitimation of the stakeholders' interests; though, the solution presented above can only provide orientation for procedures executed within a firm.

40 The interest of e.g. employees in an increase of payment can contradict the interests of the unemployed in taking up employment or of customers in stable prices.

41 By the second part of this conjunction stockholders are not excluded for categorical reasons but simply because the paper assumes that they are not interested in such time-taking undertakings.

With reference to Mitchell et al. (1997), Werhane/Freeman (1999: 8) state: „To prioritize stakeholder claims one examines an organization's purpose and mission, ranking stakeholders in terms of who has legitimate or appropriate claims, and who is essential to that mission and to the survival and the flourishing of the organization."

43 „(I)n der Diskursethik (wird) die unbegrenzte Gemeinschaft aller Vernunftwesen als ,eigentliche’ Instanz der moralischen Verantwortung verstanden, wodurch der Fehlbarkeit aller empirischen Rechtfertigungsversuche Rechnung getragen werden soll“" (italics in the original). 


\subsection{Stakeholder management and the governance of the firm}

Based on its institutional economic roots, the RPO approach throws light on the organizational and management consequences of bargaining transactions. The consequences of negotiations, which have taken place in the course of a bargaining transaction, are to be realized within the organizational settings of both transaction partners, i. e., by means of managerial transactions. Customer integration leads thus to a linkage of bargaining and managerial transactions and with it to an entanglement of organizational structures which relate to markets and organizations as well.

If a firm's measures directed at customer integration are missing or are deficiently designed and realized, competitive disadvantages will probably accrue therefrom. From the perspective of the theory of the firm, therefore, customer integration is inevitable. It will gain in importance, the more a firm is in need of the customer's cooperation in order to achieve relevant resources or the customer's co-government of the joint value-creation process. A firm can successfully interact with its customers but neglect many of its other stakeholders. Other firms, however, can face competitive disadvantages because of a disregard of stakeholders not accommodated by the market. In the meantime the policy of many firms is directed at the creation of reliable relationships to their stakeholders, or ethical reputation, respectively.

As regards the management dimension, customer integration can be considered a special case of stakeholder integration. The gateway to the consideration of problems based on the stakeholder approach is the restriction of the supplier's autonomy on the direction and management of those resources, which are involved in the joint production process with the customer. If a similar gateway from the market into the organization is opened for other stakeholder groups than the customers, joint business economic-ethical issues can be dealt with in an enhanced manner. Compared to customer integration, governance structures related to stakeholder integration need not to be formed up in all organizational, institutional, and technical details with respect to each stakeholder or stakeholder group.

From the perspective of an economic-ethical theory of the firm, the responses to stakeholders' expectations are regular management tasks. This is in line with the communication of the output in the market and the adoption of information from the market, or from communications with single customers, respectively. Customer integration as well as the communication with other stakeholders requires a linkage between the internal and external organization of a firm. It is the task of management to generate the presuppositions for communication and mutual understanding which are the basis for knowledge exchange or information processes. From the perspective of the RPO approach, a firm's corporate governance directed at communications with stakeholders is named ,stakeholder management".

The firm has to react to the extended range of tasks accruing from stakeholder integration. First of all, an adequate governance structure is required, i. e. the implementation of new structures or a change of available organizational, institutional, and technical presuppositions for the firm's managerial transactions. Stakeholder management can extend into performance management, knowledge management, marketing management, human resource management, customer relationship management, organizational design, institutional design, a. s. o. The procurement or development of the 
required human resources, e. g., has to account for the actual or future skills of employees, i. e., their ability to communicate or to execute stand-alone thinking and acting. These skills are of particular importance at a firm's interfaces with customers and other stakeholders. As the management cannot foresee the course of processes characterized by interest conflicts and the need for dealing with them in negotiation procedures, stakeholder communication necessitates the management's acceptance of ranges of autonomous action for the employees (Maclagan 2007).

\section{Summary and conclusions}

The paper outlined and discussed two steps related to the statement and analysis of the ethical dimensions of a business-economic theory (step one) and their extension towards a development of a business economic-ethical theory (step two). This division reflects the positive-normative dichotomy that has resulted from the value-judgment controversy in economics. Throughout the paper, however, the positive-normative dichotomy is addressed not in order to avoid normative theory-developments in general, but in order to make them the subject of control and reflection.

There are two gateways to the achievement of the before-mentioned aims: First, the $\mathrm{RPO}$ approach's concept of integrative production which throws light on the important role of the customer, be it an individual or a firm in the business process; second, the stakeholder approach which is already a management approach within business ethics and matches with the management dimensions of customer as well as stakeholder integration. Even though not elaborated on in this paper, by reason of its characteristics as a descriptive, or instrumental, or normative approach the stakeholder approach also allows for a step-wise and controlled introduction of normativity.

By reason of space limitations, the paper has mainly confined itself to the discussion of the first step. Even the measures which are put into relation to this step are only presented in a sketchy manner. The RPO approach is presented throughout the paper as a starting point appropriate to the statement and analysis of the ethical dimensions of a business-economic theory. It is also assumed to be a promising candidate for the achievement of a more-sophisticated business economic-ethical theory. Notwithstanding it is obvious that there remains much work to be undertaken on both steps.

Because of its characteristics, the RPO approach is a well-suited and promising candidate. However, it is only an example. Every business-economic theory can be inspected with respect to its ethical dimensions, i. e., can be transformed in an ethically informed economics approach. From a general point of view on business economics, it is not required that every economic theory needs to be extended into a full-fledged ethical version; in addition, not every business economic-ethical theory needs to be applied to all cases in its fully developed version. The paper suggests that business economic scholars begin with a broadly disposed program addressing the ethical dimensions of their theories, and then decide case-by-case if and how to proceed. 


\section{References}

Albach, H. (2005): Betriebswirtschaftslehre ohne Wirtschaftsethik!, in: Zeitschrift für Betriebwirtschaft, 75(9), 809-831.

Albach, H. (2008): Grundsätzliche Überlegungen zur Allgemeinen Ethik und zur Rolle der Unternehmensethik in der Unternehmenstheorie, in: Scherer, A. G./Patzer, M. (Eds.): Betriebswirtschaftslehre und Unternehmensethik, Wiesbaden: Gabler, 3-13.

Albert, H. (1965): Wertfreiheit als methodisches Prinzip. Zur Frage der Notwendigkeit einer normativen Sozialwissenschaft, in: Topitsch, E. (Ed.): Logik der Sozialwissenschaften, Köln et al.: Kiepenheuer \& Witsch, 181-210.

Albert, H. (1980): Traktat über kritische Vernunft, Tübingen: Mohr Siebeck.

Blang, M. (1998): The Positive-Normative Distinction, in: Davis, J. B. (Ed.): The Handbook of Economic Methodology, Cheltenham et al., Edward Elgar, 370-374.

Bowie, N. E./ Werhane, P. H (2005): Management Ethics, Malden (MA) et al.: Blackwell.

Brink, A. (2008): Business Ethics and the Rhetoric of Reaction, in: Cowton, Ch./ Haase, M. (Eds.): Trends in Business and Economic Ethics, Heidelberg et al.: Springer, 153-173.

Cappelen, A. (2004): Two Approaches to Stakeholder Identification, in: Zeitschrift für Wirtschafts- und Unternehmensethik (zfwu), 5(3), 319-325.

Chmielewicz, K. (1979): Forschungskonzeptionen in der Wirtschaftswissenschaft, Stuttgart: Poeschel.

Coase, R. H. (1937): The Nature of the Firm, in: Economica, 4(16), 386-405.

Commons, J. R. (1931): Institutional Economics, in: The American Economic Review, 21(3), 648-657.

Corsten, H./ Gössinger, R. (2005) (Eds.): Dienstleistungsökonomie: Beiträge zu einer theoretischen Fundierung, Berlin: Duncker \& Humblot.

Cowton, Ch. (2008): On Setting the Agenda for Business Ethics Research, in: Cowton, Ch./ Haase, M. (2008) (Eds.): Trends in Business and Economic Ethics, Heidelberg et al.: Springer, 11-29.

Cowton, Ch./ Haase, M. (2008) (Eds.): Trends in Business and Economic Ethics, Heidelberg et al.: Springer.

Darby, M./ Karni, E. (1973): Free Competition and the Optimal Amount of Fraud, in: Journal of Law and Economics, 16(1), 67-88.

Donaldson, T./ Preston, L. E. (1995): The Stakeholder Theory of the Corporation: Concepts, Evidence, and Implications, in: Academy of Management Review, 20(1), 65-91.

Ehret, M. (2007): The Evolution of Business Markets: New Perspectives Provided by the Theory of the Firm, Berliner Reihe zum Marketing, Arbeitspapier Nr. 2, http:// www.wiwiss.fu-berlin/institute/marketing/forschung/arbeitspapiere/index.html.

Engelhardt, $W$. (1966): Grundprobleme der Leistungslehre, dargestellt am Beispiel der Warenhandelsbetriebe, in: Zeitschrift für betriebswirtschaftliche Forschung, 18(2), 158-179.

Fließ, S./ Kleinaltenkamp, M. (2004): Blueprinting the Service Company: Managing Service Processes Efficiently and Effectively, in: Journal of Business Research, 57(4), 392-404.

Frauendorf, J./ Kähm, E./ Kleinaltenkamp, M. (2007): Business-to-Business Markets - Status Quo and Future Trends, in: Journal of Business Market Management, 1(1), 7-39.

Freeman, R. E. (1984): Strategic Management: A Stakeholder Approach, Boston: Pitman.

Freeman, R. E. (1994): The Politics of Shareholder Theory: Some Future Directions, in: Business Ethics Quarterly, 4(4), 409-422. 
Freeman, R. E. (2004): The Stakeholder Approach Revisited, in: Zeitschrift für Wirtschafts- und Unternehmensethik (zfwu), 5(3), 228-241.

Freeman, R. E./ Wicks, A. C./ Parmar, B. (2004): Stakeholder Theory and "The Corporate Objective Revisited", in: Organization Science, 15(3), 364-369.

French, P. (1979): The Corporation as a Moral Person, in: American Philosophical Quarterly, 16(3), 207-215.

Führ, M./ Bizer, K./ Feindt, P. H. (2007) (Eds.): Menschenbilder und Verhaltensmodelle in der wissenschaftlichen Politikberatung: Möglichkeiten und Grenzen interdisziplinärer Verständigung, Baden-Baden: Nomos.

Gutenberg, E. (1929): Die Unternehmung als Gegenstand betriebswirtschaftlicher Theorie, Berlin et al.: Industrieverlag Spaeth \& Linde.

Haase, M. (2000): Institutionenökonomische Betriebswirtschaftstheorie: Allgemeine Betriebswirtschaftslehre auf sozial- und institutionentheoretischer Grundlage, nbf 261, Wiesbaden: Gabler.

Haase, M. (2003): Kommunikation in Produktionsprozessen: Information, Wissensentstehung und Wissensverwendung in der Theorie der Unternehmung, Business to Business Marketing, Arbeitspapier Nr. 14 der Berliner Reihe, edited by Michael Kleinaltenkamp.

Haase, M./ Chatrath, St./ Saab, S. (2008): German and Anglo-Saxon Approaches to Services and Services Marketing: Taking Sock - Looking ahead, Berliner Reihe zum Marketing, Working Paper No. 4, http://www.wiwiss.fu-berlin/institute/marketing/forschung/ arbeitspapiere/index.html.

Haase, M./ Kleinaltenkamp, M. (2004): From the Old Economy Towards the New Economy: Managing the Transformation from the Marketing Point of View, in: Fandel, G./ Backes-Gellner, U./ Schlüter, M./ Staufenbiel, J. E. (Eds.): Modern Concepts of the Theory of the Firm: Managing Enterprises of the New Economy, Berlin et. al.: Springer, 85-109.

Homann, K. (1994): Ethik und Ökonomik. Zur Theoriestrategie der Wirtschaftsethik, in: Homann, K. (Eds.): Wirtschaftsethische Perspektiven, Berlin: Duncker \& Humblot, 9-30.

Homann, K./Suchanek, A. (1987): Wirtschaftsethik - Angewandte Ethik oder Beitrag zur Grundlagendiskussion? in: Biervert, B./ Held, M. (Eds.): Ökonomische Theorie und Ethik. Frankfurt am Main/New York: Suhrkamp, 101-121.

Homann, K./ Suchanek, A. (2000): Ökonomik: Eine Einführung, Tübingen: Mohr Siebeck.

Hunt, S. D./ Duban, D. F. (2002): Competition in the Third Millenium: Efficiency or Effectiveness? Jornal of Business Research 55(2), 97-102.

Kleinaltenkamp, M. (1997): Integrativität als Kern einer umfassenden Leistungslehre, in: Backhaus, K./ Günter, B./ Kleinaltenkamp, M./ Plinke, W./ Raffée, H. (Eds.): Marktleistung und Wettbewerb: Strategische und operative Perspektiven der marktorientierten Leistungsgestaltung, Wiesbaden: Gabler, 83-115.

Kleinaltenkamp, M. (2005): Integrativität als Baustein einer Theorie der Dienstleistungsökonomie, in: Corsten, H./ Gössinger, R. (Hrsg.): Dienstleistungsökonomie: Beiträge zu einer theoretischen Fundierung, Berlin: Duncker \& Humblot, 55-83.

Kleinaltenkamp, M./ Fließ, S./ Jacob, F. (1996) (Eds.): Customer Integration: Von der Kundenorientierung zur Kundenintegration, Wiesbaden: Gabler.

Kleinaltenkamp, M./ Haase, M. (1999): Externe Faktoren in der Theorie der Unternehmung, in: Albach, H./ Eymann, E./ Luhmer, A./ Stevens, M. (Eds.): Die Theorie der Unternehmung in Forschung und Praxis, Berlin: Springer, 167-194. 
Kleinaltenkamp, M./ Jacob, F. (2002): German Approaches to Business-to-Business Marketing Theory: Origins and Structure, in: Journal of Business Research, 55(2), 149-155.

Kleinaltenkamp, M./ Marra, A. (1995): Institutionenökonomische Aspekte der "Customer Integration," in: Kaas, K. P. (Ed.): Marketing und Neue Institutionenlehre, Sonderheft Nr. 35 der Zeitschrift für betriebswirtschaftliche Forschung (ZfbF), 101-117.

Koslowski, P. (1986): Ethik des Kapitalismus (mit einem Kommentar von James M. Buchanan), Tübingen: Mohr Siebeck.

Koslowski, P. (1992): Ethical Economy as Synthesis of Economic and Ethical Theory, in: Koslowski, P. (Ed.): Ethics in Economics, Business, and Economic Policy, Berlin: Springer, 15-56.

Koslowski, P. (2008): Some Principles of Ethical Economy, in: Cowton, C./ Haase, M. (Eds.): Trends in Business and Economic Ethics, Heidelberg et al.: Springer, 31-69.

Küpper, H.-U. (2005): Analytische Wirtschaftsethik als betriebswirtschaftliches Konzept zur Behandlung von Wertkonflikten in Unternehmungen, in: Zeitschrift für Betriebswirtschaft, 75(9), 833-857.

Küpper, H.-U. (2007): Business Ethics in Germany. Problems, Concepts, and Functions, in: Zeitschrift für Wirtschafts- und Unternehmensethik (zfwu), 8(3), 250-269.

Ladd, J. (1992): Bhophal, moralische Verantwortung und Bürgertugend, in: Lenk, H./ Maring, M. (Eds.): Wirtschaft und Ethik, Stuttgart: Reclam, 285-300.

Lenk, H./ Maring, M. (1992): Verantwortung und Mitverantwortung bei korporativem und kollektivem Handeln, in: Lenk, H./ Maring, M. (Eds.): Wirtschaft und Ethik, Stuttgart: Reclam, 153-164.

Leschke, M./ Pies, I. (Eds.): Wissenschaftliche Politikberatung: Theorie, Konzepte, Institutionen, Stuttgart: Lucius \& Lucius.

Machan, T. R./ Chesher, J. E. (2002): A Primer on Business Ethics, Lanham (MD): Rowman \& Littlefield.

Maclagan, P. (2007): Hierarchical Control or Individuals' Moral Autonomy? Addressing a Fundamental Tension in the Management of Business Ethics, in: Business Ethics: A European Review, 16(1), 48-61.

Marcoux, A. (2008): Business Ethics, Stanford Encyclopedia of Philosophy, http:// plato.stanford.edu/entries/ethics-business/ (First published Wed 16 April, 2008).

Mitchell, R. K./ Agle, B. A./ Wood, D. J. (1997): Toward a Theory of Stakeholder Identification and Salience: Defining the Principle of Who and What Really Counts, in: Academy of Management Review, 22(4), 853-886.

Musschenga, A. W. (1999): Empirical Science and Ethical Theory: The Case of Informed Consent, in: Musschenga, A. W./ van der Steen, W.J. (Eds.): Reasoning in Ethics and Law. The Role of Theory, Principles and Facts, Aldershot (UK)/Brookfield (VT), 183-205.

Myrdal, G. (1976): Das politische Element in der nationalökonomischen Doktrinbildung. Schriftenreihe des Forschungsinstituts der Friedrich-Ebert-Stiftung, Nr. 24, Bonn.

Nelson, E. S. (2001): Kant and the Art of Political Prudence, in: Gerhardt, V./ Horstmann, R.-P./ Schumacher, R. (Eds.): Kant und die Berliner Aufklärung: Akten des IX. Internationalen Kant-Kongresses, Vol. 4, Berlin and New York: de Gruyter, 220-227.

Nelson, P. (1970): Information and Consumer Behavior, in: Journal of Political Economy, 78(1), 311-329.

Priddat, B. P. (1998): Moralischer Konsum: 13 Lektionen über die Käuflichkeit, Stuttgart: Hirzel.

Rieger, W. (1928): Einführung in die Privatwirtschaftslehre, Nürnberg: Krische. 
Saab, S. (2008): Leistungslehre und Service-Dominant Logic for Marketing - Ein kritischer Vergleich, in: Benkenstein, M. (Ed.): Neue Herausforderungen an das Dienstleistungsmarketing, Wiesbaden: Gabler, 217-238.

Schönpflug, F. (1954): Betriebswirtschaftslehre: Methoden und Hauptströmungen. 2. erweiterte Auflage von „Das Methodenproblem in der Einzelwirtschaftslehre“, edited by Hans Seischab, Stuttgart: Poeschel.

Schramm, M. (2008): Ökonomische Moralkulturen: Die Ethik differenter Interessen und der plurale Kapitalismus, Marburg: Metroplis.

Schreyögg, G. (1999): Horst Steinmann - 65 Jahre, in: Forum Wirtschaftsethik 4/1999, http:// www.akademie-rs.de/wirtschaftsethik/heft499/person.htm (Zugriff am 5.3.2007).

Shionoya, Y. (2008): Economic Ethics: A Sytematic Integration, in: Cowton, Ch./ Haase, M. (Eds.): Trends in Business and Economic Ethics, Heidelberg et al.: Springer, 71-89.

Steinmann, H. (2008): Betriebswirtschaftslehre und Unternehmensethik: Ein Ausblick, in: Scherer, A. G./ Patzer, M. (Eds.): Betriebswirtschaftslehre und Unternehmensethik, Wiesbaden: Gabler, 339-351.

Steinmann, H./ Löhr, A. (1994): Grundlagen der Unternehmensethik, Stuttgart: Poeschel.

Stoney, C./ Winstanley, D. (2001): Stakeholding: Confusion or Utopia? Mapping the Conceptual Terrain, in: Journal of Management Studies, 38(5), 603-626.

Ulrich, P. (1987): Die Weiterentwicklung der ökonomischen Rationalität, in: Biervert, B./ Held, M. (Eds.): Ökonomische Theorie und Ethik, Frankfurt a. M./New York, 122-149.

Ulrich, P. (2001): Integrative Wirtschaftsethik: Grundlagen einer lebensdienlichen Ökonomie, Bern et al.: Paul Haupt.

Vargo, S. L./ Lusch, R. (2004): Evolving to a New Dominant Logic for Marketing, in: Journal of Marketing, 68(1), 1-17.

Werhane, P. H. (1985): Persons, Rights, and Corporations, Englewood Cliffs (NJ): PrenticeHall.

Werhane, P. H./ Freeman, E. (1999): Business Ethics: State of the Art, in: International Journal of Management Reviews, 1(1), 1-16.

Werner, M. H. (2006): Verantwortung, in: Düwell, M./ Hübenthal, C./ Werner, M. H. (Eds.): Handbuch Ethik, Stuttgart, Weimar: Metzler, 541-548.

Weyermann, M./ Schönitr, H. (1912): Grundlegung und Systematik einer wissenschaftlichen Privatwirtschaftslehre und ihre Pflege an Universitäten und Fach-Hochschulen, Karlsruhe: G. Braunsche Hofbuchdruckerei und Verlag.

Wieland, J. (1996): Ökonomische Organisation, Allokation und Status, Tübingen: J. C. B. Mohr. Wöhe, G. (1986): Einführung in die Allgemeine Betriebswirtschaftslehre, München: Vahlen. 